\title{
The role of isoflavon in reducing blood glucose levels
}

\author{
Prasetyastuti \\ Department of Biochemistry, Faculty of Medicine, Public Health, and Nursing, Universitas \\ Gadjah Mada, Yogyakarta
}

DOI: http://dx.doi.org/10.19106/JMedScie/005004201814

\section{ABSTRACT}

Plants provide excellent sources of medicinal compounds. Over 5000 flavonoids have been isolated and identified from plant sources. Flavonoids are polyphenolic compounds mainly recognized as pigments which produce the colors found in flowers, fruit and leaves. Dietary polyphenols are commonly found in plants and are abundant in fruit, vegetables, chocolate, and nuts. These polyphenols also found in beverages including tea, coffee, wine, and soy milk. Flavonoids are known to lower glucose levels, decrease cholesterol and triglycerides, and increase liver enzyme levels most likely by stimulating pancreatic insulin release. By activating cell-signaling pathways involved in controlling blood glucose levels, flavonoids aid in carbohydrate digestion, and adipose deposition. Flavonoids containing isoflavones, flavanols, flavanones, flavonols, flavones, and anthocyanins have been studied from clinic study until pre clinic study. However, not all of the studies conducted had adequate results. Isoflavone is one of the potential flavonoids that still can be explored for future research. Research on isoflavone supplementation in animals and humans in reducing blood glucose levels is still limited. Short-term supplementation did not improve blood glucose levels in postmenopausal women, while other studies suggest that the long-term isoflavone supplementation can reduce postmenopausal blood glucose levels. These findings found that isoflavone is a component of flavonoids that have potency in reducing blood glucose levels.

\section{ABSTRAK}

Tanaman merupakan sumber senyawa obat yang bagus. Lebih dari 5000 flavonoid telah di isolasi dan di identifikasi dari tumbuhan. Flavonoid merupakan senyawa polifenol terutama dikenal sebagai pigmen yang bertanggung jawab terhadap beberapa warna bunga, buah dan daun. Polifenol diet merupakan senyawa kimia yang berasal dari tumbuhan yang banyak terdapat dalam buah, sayuran, coklat, dan kacang, juga terdapat pada minuman seperti teh, kopi, anggur dan susu kedelai. Flavonoid dapat menurunkan kadar glukosa darah, kolesterol dan trigliserida plasma secara bermakna dan meningkatkan aktivitas glukokinase hepar dengan meningkatkan pelepasan insulin dari sel beta pankreas. Flavonoid mengatur pencernaan karbohidrat, deposisi jaringan adiposa, pelepasan insulin, dan ambilan glukosa dalam jaringan yang merespon terhadap insulin melalui beberapa jalur signaling sel. Flavonoid terdiri dari isoflavon, flavanol, flavanon, flavonol, flavon, dan antosiani telah dikaji mulai dari uji pre klinik sampai klinik. Namun, tidak semua penelitian yang dilakukan menunjukkan hasil yang sesuai. Salah satu flavonoid yang mungkin memberi harapan untuk penelitian masa depan adalah isoflavon. Penelitian tentang suplementasi isoflavon pada hewan dan manusia dalam menurunkan kadar glukosa darah masih terbatas. Suplementasi isoflavon jangka pendek tidak memperbaiki kadar glukosa darah pada wanita postmenopausal, sedangkan penelitian lain menunjukkan bahwa suplementasi isoflavon jangka panjang dapat menurunkan kadar glukosa darah wanita postmenopausal. Oleh karena itu isoflavon sebagai komponen flavonoid telah terbukti dapat menurunkan kadar glukosa darah.

Keywords: flavonoid - isoflavone - blood glucose level - G-6-Pase enzyme - PEPCK enzyme 


\section{INTRODUCTION}

Plants are excellent sources of medicinal compounds. Over 5000 flavonoids have been isolated and identified from plant sources. Flavonoids are polyphenolic compounds mainly recognized as pigments which produce the colors found in flowers, fruit and leaves. Beginning more than 20 years ago many studies have focused on polyphenol compounds derived from plants because they are beneficial for human health. ${ }^{1}$ The World Health Organization (WHO) recommends evaluating traditional medicinal plants because they are effective, non-toxic, and have few or no side effects so that they are excellent candidates for oral treatment.

Recently, the flavonoid rich fraction of pomegranate (PGFF) was shown to decrease fasting blood glucose significantly in streptozotocin (STZ) induced diabetic rats. $^{2}$ Treatment with O-prenilated flavonoid constituents in Melicope lunu-ankenda at dose $10 \mathrm{mg} / \mathrm{kg}$ BW given to diabetic rats significantly reduced blood glucose levels after 2 weeks returning it very close to normal values. ${ }^{3}$ Jiang et al. ${ }^{4}$ treated diabetic rats with fenugreek flavonoids at dose $0.5 \mathrm{~g}$ in $10 \mathrm{~mL}$ water intragastrically for 28 days and found significantly decreased levels of fasting blood glucose (FBG).

Another study in humans showed extract of cocoa (EC) and cocoa polyphenolic extract (CPE) can improve insulin sensitivity of HepG2 cells induced with high glucose levels. Beneficial effects were demonstrated for liver function and involved mitigating the signaling pathways for insulin while modulating production and uptake of glucose. ${ }^{5}$ Similarly, research by Ferguson et $a l .{ }^{6}$ showed soy products rich in isoflavones could lower fasting insulin in European soy consumers and lower glucose levels postOGTT significantly compared to non-soy consumers.

Research by Yun et al. ${ }^{7}$ indicated that soy isoflavones reduced body weight and improved glucose metabolism significantly in non-Asian postmenopausal women.
Furthermore, the longer the treatment with soy isoflavones, the greater the decrease in blood glucose levels. This review article comprehensively describes the main categories of the bioflavonoid family, with particular emphasis on the efficacy of polyphenols such as isoflavones which can be used in oral supplementation for control treatment to decrease blood glucose levels.

\section{DISCUSSION}

\section{Flavonoids}

Flavonoids are polyphenolic compounds mainly recognized as pigments which produce the colors found in flowers, fruit and leaves and contain many health benefits. Their salutogenetic effects range from treatments for arteriosclerosis and heart disease to hepatic dysfunction and insulin insensitivity. As chemical compounds, most polyphenols are poorly soluble in water containing a 15-carbon (C6-C3-C6) skeleton. They consist of two benzene rings joined together by a short chain of three carbon atoms. Dietary polyphenols are commonly found in plants and are abundant in fruit, vegetables, chocolate, and nuts. These polyphenols also occur in beverages including tea, coffee, wine, and soy milk. ${ }^{8,9}$ Flavonoids are known to lower blood glucose levels, decrease cholesterol and triglycerides, and increase liver enzyme levels most likely by stimulating pancreatic insulin release. By activating cell-signaling pathways involved in controlling blood glucose levels, flavonoids aid in carbohydrate digestion, and adipose deposition. Under oxidative stress conditions, research showed the negative effects of the accumulation of free radicals such as reactive oxygen species (ROS) and reactive nitrogen species (RNS). ROS and RNS are cellular by-products of human metabolism and contribute to a variety of life-threatening diseases such as coronary heart diseases, Type 2 diabetes mellitus (T2DM), obesity and cancers. ${ }^{10}$ Our previous study demonstrated that the flavonoids from Swietenia macrophyla King seeds can lower 
blood glucose levels by down regulating the hepatic enzyme, phosphoenolpyruvate carboxykinase (PEPCK). ${ }^{11}$

Flavonoids are absorbed by active transport. There are two compartments involved in the metabolism of flavonoids. The first compartment includes the small intestine, liver, and kidneys. The second compartment is the colon. Before absorption flavonoids are held in hydrolysis by lactase phlorizin hydrolase (LPH) that catalyzes some glycosides and cytosolic $\beta$-glucosidase (CBG) that are involved intracellularly with broad specificity. ${ }^{12,13}$ After absorption, flavonoids undergo three main processes: methylation, sulfation and glucuronidation. ${ }^{8,14,15}$ In the small intestine, some flavonoids are not absorbed while most absorbed are then secreted with bile in the large intestine. This process of biliary secretion is not well-understood in humans, while nearly $40 \%$ of absorbed (b)-catechin was secreted with bile back into the rat small intestine. ${ }^{16}$

\section{Classification of flavonoid}

\section{Flavanols}

Rich in flavanols (FIGURE 1), green tea extract taken orally has been found to have many health benefits and to be a significant source of monomeric flavan-3-ols. These beneficial flavanols include epicatechingallate (ECG) and epigallocatechin gallate (EGCG), which can prevent glucose absorption from intestinal lumen. The beneficial effects of $(-)$-catechin enhanced insulin-dependent glucose uptake in differentiated adipocytes in T2DM cases. ${ }^{17}$ Epigallocatechin 3-gallate acts like insulin, and as a supplement, the drug candidate enhances tyrosine phosphorylation of the insulin receptor and insulin receptor substrate-1 (IRS-1), as well as PI3K activity, while reducing phosphoenolpyruvate carboxykinase gene expression mediated by $\mathrm{PI} 3 \mathrm{~K} .{ }^{18}$ The (-)-epicatechin gallate, myricetin, quercetin, apigenin, (-)-epigallocatechin gallate, and (-)-epigallocatechin are known to reduce glucose absorption by competitive inhibition of sodium dependent glucose transporter-1 (GLUT-1). ${ }^{19}$

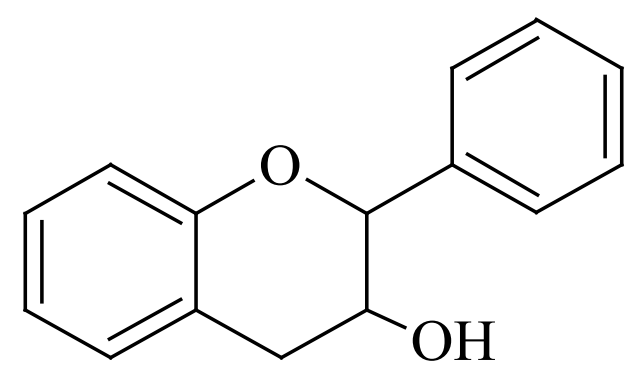

FIGURE 1. Chemical structure of flavanols ${ }^{20}$

\section{Flavanones}

The two major flavanones (FIGURE 2) are naringenin and hesperidin, which are rich in citrus fruits such as grapes, tomatoes, and oranges. ${ }^{21}$ In vivo studies of Cochlospermum vitifolium (Willd.) Spreng containing naringenin was found to decrease blood glucose levels in healthy male Wistar rats. ${ }^{22}$ Previous studies showed naringenin supports muscle glucose uptake depending on the dose but independent of insulin. ${ }^{23,24}$ One study found treatment of naringenin at a dose of $25 \mathrm{mg} / \mathrm{kg}$ BW for 45 days in a diabetic rat model significantly lowered hyperglycemia and hyperinsulinemia, after restoring lipid profiles, decreasing lipid peroxidation, through enhanced antioxidant activities and improved liver function markers. ${ }^{25,26}$ Hesperidin in doses of $10 \mathrm{~g} / \mathrm{kg}$ in the diet was found to lower blood glucose level through changes in glucose regulating enzymes. ${ }^{27} \mathrm{In}$ a hyperglycemic mice model, hesperidin had beneficial effects on glycolytic and gluconeogenesis enzymes involved in hepatic glucose metabolism. ${ }^{28,29}$

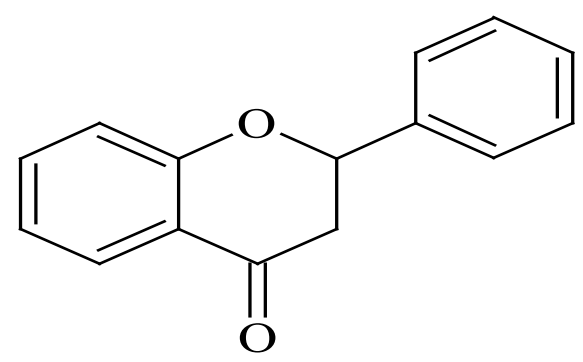

FIGURE 2. Chemical structure of flavanones ${ }^{20}$ 


\section{Flavonols}

The major flavonols (FIGURE 3) are quercetin, kaempferol, and myricetin. Quercetin and its derivatives in berries considered the primary bioactive components with many health benefits were found to activate AMPK and increase glucose levels in muscle cell uptake. Treatment of quercetin reduced hyperglycemia-stimulating GLUT4 and hepatic glucokinase (GK). Health benefits included increased liver glucose uptake, and lower hepatic glycogenolysis and gluconeogenesis. ${ }^{30-32}$ Oral supplementation of $0.5 \%$ quercetin for 2 weeks improved serum insulin level and lowered blood glucose. In the same STZ-induced diabetic mice model, intraperitoneal (IP) injection of quercetin caused lowered levels of hyperglycemia and improved glucose tolerance. Health benefits also included higher liver glucokinase activity and reductions in plasma cholesterol and triglycerides. ${ }^{33}$ In an obese diabetic mice model, dietary supplementation of $0.04 \%$ quercetin lowered blood glucose and increased insulin resistance. ${ }^{34}$ One study in 6-week-old male Wistar rats on a high-fat high-sucrose diet found quercetin supplementation at $30 \mathrm{mg} / \mathrm{kg}$ BW per day for six weeks helped to lower basal levels of glucose and insulin. ${ }^{35}$ Quercetin has been proven to be effective against obesity and diabetes by blocking digestion of intestinal starch and liver glucose production. Quercetin also increases skeletal muscle glucose uptake, and protects pancreatic islets from damage. Kaempferol extracted from the leaves of the Brazilian orchid tree (Bauhinia forficata) has been found to reduce hyperglycemia and increased glucose uptake similar to the action of insulin. ${ }^{36}$ Kaempferol caused the increase of glucose uptake in the rat soleus muscle through PI3K and protein kinase $\mathrm{C}$ (PKC) pathways and by synthesizing new glucose transporters ${ }^{37}$. As a potent antioxidant kaempferol increased TNF- $\alpha$ and IL- $1 \beta$ expression as well as lipid peroxidation. The resulting benefits improved antioxidant defense. ${ }^{38,39}$<smiles>O=c1c(O)c(-c2ccccc2)oc2ccccc12</smiles>

FIGURE 3. Chemical structure of flavonol ${ }^{20}$

\section{Flavones}

The major dietary flavones (FIGURE 4) are apigenin and luteolin. ${ }^{40,41}$ Intraperitoneal administration of apigenin significantly acts as an insulin regulating agent with anti-hyperglycemic effects. ${ }^{22}$ According to Ding et $a l .{ }^{42}$ luteolin was reported to have insulin potentiate action and increased expression and transcriptional activation of the PPAR gamma target gene. Luteolin positively influenced metabolic pathways in insulin resistance and pathophysiology of diabetes mellitus by inhibiting MCP-1 circulating levels and resistin, among other inflammatory molecules.<smiles>O=c1cc(-c2ccccc2)oc2ccccc12</smiles>

FIGURE 4. Chemical structure of flavones ${ }^{20}$

\section{Anthocyanins}

Bilberries are an abundant source of anthocyanins (FIGURE 5) and bilberry extract (BBE) has been shown to improve hyperglycemia and insulin sensitivity by influencing AMP-activated protein kinase (AMPK), GLUT-4, and metabolic enzymes. ${ }^{42}$ Cyanidin also protects hepatocytes from damage triggered by high levels of glucose by reducing the mitochondiia-mediated apoptotic pathways and improving antioxidant status by triggering AKT and inactivating $\mathrm{JNK}{ }^{43,44}$, 
<smiles>[R]C(=Cc1cc([R])c([R])c([R])c1)C([R])=Cc1c([O+])cc([R])c([R])c1[R6]</smiles>

FIGURE 5. Chemical structure of anthocyanins ${ }^{45}$

\section{Isoflavones}

Isoflavones are a type of flavonoids found in legumes, including soybean and soy products. Soy food products contain two main isoflavones: daidzein and genistein. ${ }^{40}$ Research has shown isoflavone administration can lower blood glucose levels. ${ }^{46}$ Supplementation with isoflavones is known to suppress the activities of gluconeogenic enzymes such as PEPCK and G6Pase. Soy isoflavones were also found to decrease $\beta$-oxidation of fatty acids and lipid accumulation while soy dietary supplementation could increase beneficial lipogenesis in the liver. ${ }^{47}$

One study recently found that a soysupplemented diet could provide a number of overall health benefits. Mice fed 198 ppm daidzein and $286 \mathrm{ppm}$ genistein for their entire life demonstrated better lipid profile and glucose metabolism. ${ }^{48}$ Supplementation with soy isoflavones also increased phosphorylation of AMPK. These health benefits included positive metabolic changes, such as improved mitochondrial biogenesis and glucose uptake in the skeletal muscle. ${ }^{48}$ There were also a number of reports documenting decreased blood glucose, TGF $\beta$ 1, and HbA1C levels. ${ }^{49,50}$

Other research found genistein was beneficial in the treatment of diabetes and could improve plasma lipids ${ }^{51}$, and was shown to increase insulin sensitivity. ${ }^{52}$ Genistein could also reduce fasting glucose levels in non-genetic diabetes mice. ${ }^{52}$ Supporting these findings, genistein supplementation was beneficial to improve glucose tolerance and hyperglycemia.
It was also found to increase islet $\beta$-cell expression and prolong the life of mice in a diabetic model induced by STZ. ${ }^{53}$ In dietary supplementation, isoflavones, soy protein, or genistein in combination, can have many health benefits, especially for balancing the body's metabolism. In non-obese diabetic mice models, daidzein or genistein can prevent diabetes and improve glucose homeostasis through balancing pancreatic $\beta$-cell function. ${ }^{47}$

Daily doses of isoflavones in the form of $100 \mathrm{mg}$ of aglycones for a year were found to improve insulin sensitivity and blood lipid levels of post-menopausal women with T2DM. ${ }^{54}$ Oppositely, daily isoflavone doses of $132 \mathrm{mg}$ for 3 months showed no improvement in plasma A1C, blood glucose, nor insulin levels in postmenopausal women with T2DM. ${ }^{18}$ While these contradictory results may possibly be due to treatment dosage and duration differences, a number of studies, both in vitro and in vivo demonstrated health benefits of isoflavone supplementation finding many anti-obesity and anti-diabetic results. Genistein was seen at dose $0.02 \%$ to suppress the onset of DM and increased glucose homeostasis through the function of pancreatic beta cell stabilization in non-obese diabetic mice. ${ }^{47}$

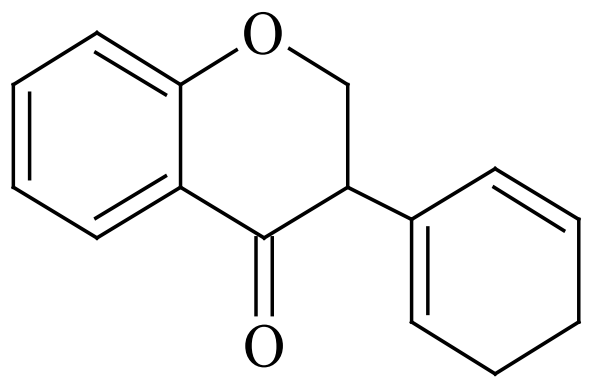

FIGURE 6. Chemical structure of isoflavones ${ }^{20}$

\section{Role of isoflavone in reducing the blood glucose}

All members of the bioflavonoid family are important for health due to the ability to control blood glucose levels. Recent research has shown that isoflavones can especially suppress gluconeogenic enzyme activity such as PEPCK and G6Pase, lipid profile, and can increase beta oxidation of 
fatty acids and lipogenesis in liver. PEPCK is an essential enzyme for gluconeogenesis so that the enzyme suppression results in the formation of glucose from sources other than dietary carbohydrates and as a result it can reduce blood glucose levels in rat liver. ${ }^{47}$ G6Pase is an enzyme that converts G6P to glucose so that suppression of G6Pase also results in a decrease in blood glucose levels. Meta-analysis by Zhan et al. ${ }^{7}$ reported that soy isoflavone supplementation significantly reduced body weight and improved glucose metabolism compared in non-Asian postmenopausal women. ${ }^{7}$ Isoflavones at dose $100 \mathrm{mg}$ for one year in postmenopausal women can improve insulin sensitivity and blood lipid parameter, but low doses for only 3 months cannot improve plasma A1C, blood glucose and insulin levels. ${ }^{20,54}$ Soy supplements have been shown to improve lipid profile, metabolism of glucose, increase AMPK phosphorylation and cause favorable metabolic changes and skeletal muscle glucose uptake, while decreasing KGD, TGF $\beta 1$ and $\mathrm{HbA} 1 \mathrm{C}$ in mice. ${ }^{48-50}$ Genistein reduces the expression of PPARs and $\mathrm{C} / \mathrm{EBP}$, modulates glucose metabolism and insulin levels, improves lipids so insulin sensitivity increases, and improves glucose tolerance and hyperglycemia. ${ }^{52,53,55,56}$ It also increases beta cell proliferation by modulating signaling pathways (activation calmodulin kinase II and $\mathrm{Ca}^{2+}$ signaling), ${ }^{57}$ and suppresses NF-kB, ERK-1/2 and JAK/ STAT pathways ${ }^{58}$ in pancreatic beta cells stimulating CAMP/PKA signaling. ${ }^{59,60}$

\section{CONCLUSIONS}

Short-term isoflavone supplementation does not improve blood glucose levels in postmenopausal women, while other studies suggest long-term isoflavone supplementation can reduce postmenopausal blood glucose levels. These findings demonstrate that isoflavones as a component of flavonoids can be used to reduce blood glucose levels by three mechanisms: suppress gluconeogenic enzyme in hepar, increase lipogenesis, and stimulate glucose uptake and metabolism. Research on isoflavone supplementation in animals and humans in reducing blood glucose levels is still limited.

\section{ACKNOWLEDGEMENT}

I am very grateful to my colleague, Dr. Erna Kristin, from Department of Pharmacology and Therapy, Faculty of Medicine, Public Health and Nursing, Universitas Gadjah Mada, Yogyakarta, Indonesia for her kind help in writing this article.

\section{REFERENCES}

1. Barnes S, Prasain J. Current progress in the use of traditional medicines and nutraceuticals. Curr Opin Plant Biol 2005; 8:324-28.

http://dx.doi.org/10.1016/j.pbi.2005.03.010

2. Ankita P, Deepti B, Nilam M. Flavonoid rich fraction of Punica granatum improves early diabetic nephropathy by ameliorating proteinuria and disturbed glucose homeostasis in experimental animals. Pharmaceut Biol 2015; 53(1): 61-71. http://dx.doi.org/10.3109/13880209.2014.910533

3. George S, Nair A, Johnson AJ, Venkataraman R, Baby S. O-prenylated flavonoid, an antidiabetes constituent in Melicope lunuankenda. J Ethnopharmacol 2015; 168: 158-63.

http://dx.doi.org/10.1016/j.jep.2015.03.060

4. Jiang W, Si L, Li P, Bai B, Qu J, Hou $\mathrm{B}$, et al. Serum metabonomics study on antidiabetic effects of fenugreek flavonoids in streptozotocin-induced rats. Journal of Chromatography $B$ 2018; 1092:466-72.

http://dx.doi.org/10.1016/j.jchromb.2018.06.041

5. Cordero-Herrera I, Martín MA, Goya L, Ramos S. Cocoa flavonoids attenuate high glucose-induced insulin signaling blockade and modulate glucose uptake and production in human HepG2 cells. Food Chem Toxicol 2014; 64:10-9. http://dx.doi.org/10.1016/j.fct.2013.11.014

6. Ferguson JF, Ryan MF, Gibney ER, Brennan L, Roche HM, Reilly MP. 
MBBS. Dietary isoflavone intake is associated with evoked responses to inflammatory cardiometabolic stimuli and improved glucose homeostasis in healthy volunteers. Nutr Metab Cardiovasc Dis 2014; 24(9):996-1003. http://dx.doi.org/10.1016/j.numecd.2014.03.010

7. Zhang YB, Chen WH, Guo JJ, Fu ZH, Yi C, Zhang M, Na XL. Review, Soy isoflavone supplementation could reduce body weight and improve glucose metabolism in non-Asian postmenopausal women: a metaanalysis. Nutrition 2013; 29: 8-14. http://dx.doi.org/10.1016/j.nut.2012.03.019

8. Manach C, Scalbert A, Morand C, Rémésy C, Jiménez L. Polyphenols: food sources and bioavailability. Am J Clin Nutr 2004; 79:727-47. http://dx.doi.org/10.1093/ajcn/79.5.727

9. Torabian S, Haddad E, Rajaram S, Banta J, Sabat J. Acute effect of nut consumption on plasma total polyphenols, antioxidant capacity and lipid peroxidation. J Hum Nutr Diet 2009; 22(1):64-71. http:/dx.doi.org/10.1111/j.1365-277X.2008.00923x

10. Batra P, Sharma AK. Anti-cancer potential of flavonoids: recent trends and future perspectives. Biotech 2013; 3:439-59.

http://dx.doi.org/10.1007/s13205-013-0117-5

11. Prasetyastuti, Sunarti, Sadewa AH, Mustofa. Effect of 7-hydroxy-2-(4hydroxy-3-methoxy-phenyl)-chroman4-one (swietenia macrophylla king seed) on retinol binding protein- 4 and phosphoenolpyruvate carboxykinase gene expression in type 2 diabetic rats. Rom J Diabetes Nutr Metab Dis 2016; 23(3):255-65.

http://dx.doi.org/10.1515/rjdnmd-2016-0030

12. Day AJ, Ca-ada FJ, Diaz JC, Kroon PA, Mclauchlan R, Faulds CB, et al. Dietary flavonoid and isoflavone glycosides are hydrolysed by the lactase site of lactase phlorizin hydrolase. FEBS Lett 2000; 468:166-70.

http://dx.doi.org/10.1016/S0014-5793(00)01211-4

13. Németh K, Plumb GW, Berrin JG,
Juge N, Jacob R, Naim HY, et al. Deglycosylation by small intestinal epithelial cell beta-glucosidases is a critical step in the absorption and metabolism of dietary flavonoid glycosides in humans. Eur J Nutr 2003; 42(1):29-42.

http://dx.doi.org/10.1007/s00394-003-0397-3

14. Cazarolli LH, Zanatta L, Alberton EH, Figueiredo MSRB, Folador P, Damazio $\mathrm{RG}$, et al. MB Mini-Rev Med Chem 2008;8:429-1440,

15. ScalbertA, Williamson G. Dietary intake and bioavailability of polyphenols. J Nutr 2000; 130 (8S suppl):2073S-85S.

16. Hackett AM. The metabolism of flavonoid compounds in mammals. Prog Clin Biol Res 1986; 213:177-94.

17. Gonzalez S, Jayagopal V, Kilpatrick ES, Chapman T, Atkin SL. Effects of isoflavone dietary supplementation on cardiovascular risk factors in type 2 diabetes. Diabetes Care 2007; 30:1871-73. http://dx.doi.org/10.2337/dc06-1814

18. Cho SY, Park PJ, Shin HJ, Kim YK, Shin DW, Shin ES, et al. (-)-catechin suppresses expression of kruppel-like factor 7 and increases expression and secretion of adiponectin protein in 3T3-L1 cells. Am J Physiol Endocrinol Metab 2007; 292:E1166-72. http://dx.doi.org/10.1152/ajpendo.00436.2006

19. Anton S, Melville L, Rena G. Epigallocatechin gallate (EGCG) mimics insulin action on the transcription factor FOXO1a and elicits cellular responses in the presence and absence of insulin. Cell Signal 2007; 19:378-83.

http://dx.doi.org/10.1016/j.cellsig.2006.07.008

20. Shimizu M, Kobayashi Y, Suzuki M, Satsu H, Miyamoto Y. Bio Factors 2000; 13:61-5.

http://dx.doi.org/10.1002/biof.5520130111

21. Jung UJ, Lee MK, Jeong KS, Choi MS. The hypoglycemic effects of hesperidin and naringin are partly mediated by hepatic glucose-regulating enzymes in C57BL/KsJ-db/db mice. J Nutr 2004; 134:2499-2503. 
http://dx.doi.org/10.1093/jn/134.10.2499

22. Rauter AP, Martins, A, Borges C, MotaFilipe H, Pinto R, Sepodes B, et al. Antihyperglycaemic and protective effects of flavonoids on streptozotocininduced diabetic rats. Phytother Res 2010; 24:S133-8.

http://dx.doi.org/10.1002/ptr.3017

23. Zygmunt $\mathrm{K}$, Faubert $\mathrm{B}$, MacNeil J, Tsiani E. Naringenin, a citrus flavonoid, increases muscle cell glucose uptake via ampk. Biochem Biophys Res Commun 2010;398:178-83.

http://dx.doi.org/10.1016/j.bbrc.2010.06.048

24. Sundaram R, Shanthi P, Sachdanandam P. Effect of tangeretin, a polymethoxylated flavone on glucose metabolism in streptozotocin-induced diabetic rats. Phytomedicine 2014; 21:793-9. http://dx.doi.org/10.1016/j.phymed.2014.01.007

25. Bose M, Lambert JD, Ju J, Reuhl KR, Shapses S.A, Yang CS. The major green tea polyphenol, (-)-epigallocatechin3-gallate, inhibits obesity, metabolic syndrome, and fatty liver disease in highfat-fed mice. J Nutr 2008; 138:1677-83. http://dx.doi.org/10.1093/jn/138.9.1677

26. Tsuda T, Ueno Y, Yoshikawa T, Kojo $\mathrm{H}$, Osawa T. Microarray profiling of gene expression in human adipocytes in response to anthocyanins. Biochem Pharmacol 2006; 71:1184-97.

http://dx.doi.org/10.1016/j.bcp.2005.12.042

27. Akiyama S, Katsumata S, Suzuki K, Ishimi $\mathrm{Y}, \mathrm{Wu} \mathrm{J}$, Uehara M. Dietary hesperidin exerts hypoglycemic and hypolipidemic effects in streptozotocininduced marginal type 1 diabetic rats. J Clin Biochem Nutr 2010; 46:87-92. http://dx.doi.org/10.3164/jcbn.09-82

28. Jung UJ, Lee MK, Park YB, Kang MA, Choi MS. Effect of citrus flavonoids on lipid metabolism and glucose-regulating enzyme mRNA levels in type-2 diabetic mice. Int. J. Biochem. Cell Biol 2006; 38:1134-45.

http://dx.doi.org/10.1016/j.biocel.2005.12.002

29. Jung UJ, Choi MS. Obesity and its metabolic complications: The role of adipokines and the relationship between obesity, inflammation, insulin resistance, dyslipidemia and nonalcoholic fatty liver disease. Int J Mol Sci 2014; 15:6184-6223.

http://dx.doi.org/10.3390/ijms15046184

30. Alam MM, Meerza D, Naseem I. Protective effect of quercetin on hyperglycemia, oxidative stress and DNA damage in alloxan induced type 2 diabetic mice. Life Sci 2014; 109:8-14. http://dx.doi.org/10.1016/j.lfs.2014.06.005

31. Kobori M, Masumoto S, Akimoto Y, Takahashi Y. Dietary quercetin alleviates diabetic symptoms and reduces streptozotocin-induced disturbance of hepatic gene expression in mice. Mol Nutr Food Res 2009; 53:859-68. http://dx.doi.org/10.1002/mnfr.200800310

32. $\mathrm{Xu} \mathrm{M,} \mathrm{Hu} \mathrm{J,} \mathrm{Zhao} \mathrm{W,} \mathrm{Gao} \mathrm{X,} \mathrm{Jiang}$ C, Liu K, et al. Quercetin differently regulates insulin-mediated glucose transporter 4 translocation under basal and inflammatory conditions in adipocytes. Mol Nutr Food Res 2014; 58:931-41.

http://dx.doi.org/10.1002/mnfr.201300510

33. Vessal $M$, Hemmati $M$, Vasei $M$. Antidiabetic effects of quercetin in streptozocin-induced diabetic rats. Comp Biochem Physiol 2013: C 135:357-64.

34. Jeong SM, Kang MJ, Choi HN, Kim JH, Kim JI. Quercetin ameliorates hyperglycemia and dyslipidemia and improves antioxidant status in type 2 diabetic $\mathrm{db} / \mathrm{db}$ mice. Nutr Res Pract 2012; 6:201-7.

http://dx.doi.org/10.4162/nrp.2012.6.3.201

35. Arias N, Macarulla MT, Aguirre L, Martinez-Castano MG, Portillo MP. Quercetin can reduce insulin resistance without decreasing adipose tissue and skeletal muscle fat accumulation. Genes Nutr 2014; 9. http://dx.doi.org/10.1007/s12263-013-0361-7

36. Jorge AP, Horst H, de Sousa E, Pizzolatti MG, Silva FR. Insulinomimetic effects of kaempferitrin on glycaemia and on $14 \mathrm{c}$-glucose uptake in rat soleus muscle. Chem Biol Interact 2004; 149:89-96. 
http://dx.doi.org/10.1016/j.cbi.2004.07.001

37. Zanatta L, Rosso A, Folado P, Figueiredo MS, Pizzolatti MG, Leite LD, et al. Insulinomimetic effect of kaempferol 3-neohesperidoside on the rat soleus muscle. J Nat Prod 2008; 71:532-35. http://dx.doi.org/10.1021/np070358+

38. Al-Numair KS, Chandramohan G, Veeramani C, Alsaif MA. Ameliorative effect of kaempferol, a flavonoid, on oxidative stress in streptozotocininduced diabetic rats. Redox Rep 2015; 20:198-209.

http://x.doi.org/10.1179/1351000214Y.0000000117

39. Ali AA, Velasquez MT, Hansen CT, Mohamed AI, Bhathena SJ. Modulation of carbohydrate metabolism and peptide hormones by soybean isoflavones and probiotics in obesity and diabetes. J Nutr Biochem 2005; 16:693-9. http://dx.doi.org/10.1016/j.jnutbio.2005.03.011

40. Crozier A, Jaganath IB, Clifford MN. Dietary phenolics: Chemistry, bioavailability and effects on health. Nat Prod Rep 2009; 26:1001-43. http://dx.doi.org/10.1039/b802662a

41. Abo-Salem Osama, M. Kaempferol attenuates the development of diabetic neuropathic pain in mice: Possible anti-inflammatory and anti-oxidant mechanisms. Maced J Med Sci 2014; $7: 424$.

http://dx.doi.org/10.3889/oamjms.2014.073

42. Ding L, Jin D, Chen $X$. Luteolin enhances insulin sensitivity via activation of PPAR $\gamma$ transcriptional activity in adipocytes. J Nutr Biochem 2010; 21:941-7.

http://dx.doi.org/10.1016/j.jnutbio.2009.07.009

43. Takikawa M, Inoue S, Horio F, Tsuda T. Dietary anthocyanin-rich bilberry extra Ameliorates hyperglycemia and insulin sensitivity via activation of AMPactivated protein kinase in diabetic mice. J Nutr 2010; 140:527-33. http://dx.doi.org/10.3945/jn.109.118216

44. Zhu W, Jia Q, Wang Y, Zhang Y, Xia M. The anthocyanin cyanidin-3-o$\beta$-glucoside, a flavonoid, increases hepatic glutathione synthesis and protects hepatocytes against reactive oxygen species during hyperglycemia: Involvement of a camp-pka-dependent signaling pathway. Free Radic Biol Med 2012; 52: 314-327.

http://x.doi.ong/10.1016j.freeradbiomed2011.10.483

45. Khoo HE, Azlan A, Tang ST, Lim SM. Anthocyanidins and anthocyanins: colored pigments as food, pharmaceutical ingredients and the potential health benefits. Food Nutr Res 2017; 61: 1-21.

http://dx.doi.org/10.1080/16546628.2017.1361779

46. Ali AA, Velasquez MT, Hansen CT, Mohamed AI, Bhathena SJ. Modulation of carbohydrate metabolism and peptide hormones by soybean isoflavones and probiotics in obesity and diabetes. $\mathrm{J}$ Nutr Biochem 2005; 16:693-9. http://dx.doi.org/10.1016/j.jnutbio.2005.03.011

47. Choi MS, Jung UJ, Yeo J, Kim MJ, Lee MK. Genistein and daidzein prevent diabetes onset by elevating insulin level and altering hepatic gluconeogenic and lipogenic enzyme activities in nonobese diabetic (NOD) mice. Diabetes Metab Rev 2008; 24:74-81.

http://dx.doi.org/10.1002/dmrr.780

48. Cederroth CR, Vinciguerra M, Gjinovci A, Kuhne F, Klein M, Cederroth M, et al. Dietary phytoestrogens activate amp-activated protein kinase with improvement in lipid and glucose metabolism. Diabetes 2008; 57:117685.

http://dx.doi.org/10.2337/db07-0630

49. Gupta SK, Dongare S, Mathur R, Mohanty IR, Srivastava S, Mathur S, et al. Genistein ameliorates cardiac inflammation and oxidative stress in streptozotocin-induced diabetic cardiomyopathy in rats. Mol Cell Biochem 2015; 408:63-72.

http://dx.doi.org/10.1007/s11010-015-2483-2

50. Kim JH, Kang MJ, Choi HN, Jeong SM, Lee YM, Kim JI. Quercetin attenuates fasting and postprandial hyperglycemia in animal models of diabetes mellitus. Nutr Res Pract 2011; 5:107-11. http://dx.doi.org/10.4162/nrp.2011.5.2.107 
51. Mezei O, Banz WJ, Steger RW, Peluso MR, Winters TA, Shay N. Soy isoflavones exert antidiabetic and hypolipidemic effects through the ppar pathways in obese zucker rats and murine raw 264.7 cells. J Nutr 2003; 133:1238-43.

http://dx.doi.org/10.1093/jn/133.5.1238

52. Fu Z, Gilbert ER, Pfeiffer L, Zhang Y, Fu Y, Liu D. Genistein ameliorates hyperglycemia in a mouse model of nongenetic type 2 diabetes. Appl. Physiol. Nutr Metab 2012; 37:480-8. http://dx.doi.org/10.1139/h2012-005

53. Fu Z, Zhang W, Zhen W, Lum H, Nadler $\mathrm{J}$, Bassaganya-Riera J, et al. Genistein induces pancreatic beta-cell proliferation through activation of multiple signaling pathways and prevents insulin-deficient diabetes in mice. Endocrinol 2010; 151:3026-37.

http://dx.doi.org/10.1210/en.2009-1294

54. Curtis PJ, Sampson M, Potter J, Dhatariya K, Kroon PA, Cassidy A. Chronic ingestion of flavan-3-ols and isoflavones improves insulin sensitivity and lipoprotein status and attenuates estimated 10-year CVD risk in medicated postmenopausal women with type 2 diabetes: A 1-year, double-blind, randomized, controlled trial. Diabetes Care 2012; 35:226-32.

http://dx.doi.org/10.2337/dc11-1443

55. Veitch NC. Isoflavonoids of the leguminosae. Nat Prod Rep 2007; $24: 417-64$. http://dx.doi.org/10.1039/b511238a

56. Yang W, Wang S, Li L, Liang Z, Wang L. Genistein reduces hyperglycemia and islet cell loss in a high-dosage manner in rats with alloxan-induced pancreatic damage. Pancreas 2011; 40:396-402. http://dx.doi.org/10.1097/MPA.0b013e318204e74d

57. Lee SJ, Kim HE, Choi SE, Shin HC, Kwag WJ, Lee BK, et al. Involvement of $\mathrm{Ca} 2+/$ calmodulin kinase II (CAMK II) in genistein-induced potentiation of leucine/glutamine-stimulated insulin secretion. Mol Cells 2009; 28:167-74. http://dx.doi.org/10.1007/s10059-009-0119-7

58. Song TT, Lee SO, Murphy PA, Hendrich S. Soy protein with or without isofleivones, soy germ and soy germ extract, and daidzein lessen plasma cholesterol levels in golden syrian hamsters. Exp Biol Med 2003; 228:1063-8. http://dx.doi.org/10.1177/153537020322800912

59. Kim EK, Kwon KB, Song MY, Seo SW, Park SJ, Ka SO, et al. Genistein protects pancreatic $\beta$ cells against cytokinemediated toxicity. Mol Cell Endocrinol 2007; 278:18-28. http://dx.doi.org/10.1016/j.mce.2007.08.003

60. Liu D, Zhen W, Yang Z, Carter JD, Si $\mathrm{H}$, Reynolds KA. Genistein acutely stimulates insulin secretion in pancreatic beta-cells through a cAMP-dependent protein kinase pathway. Diabetes 2006; 55:1043-50.

http:/dx.doi.org/102337/diabetes.55.04.06.db05-1089 